\title{
SUMBER BELAJAR DALAM TEORI PANCARAN (TELAAH FILOSOFIS TENTANG PENDIDIKAN)
}

\author{
Abd. Kadir \\ (Dosen PAI FTK UIN Sunan Ampel)
}

\begin{abstract}
Abstrak:
Secara luas sumber belajar merupakan pengalaman hidup yang bersifat empirik, rasional dan spiritual. Pengalaman hidup empirik didapat dari insteraksi seseorang dengan lingkungan material dan sosial, dan yang rasional dari melalui premis-premis yang dapat dipikirkan secara logis; sedangkan yang spiritual merupakan emanasi dari wujud wajib melalui akal aktif kepada Akal Mustafad. Akal yang beroperasi pada level supra mental ini memancarkan pengetahuan yang berupa bentuk tertentu kepada seseorang, karena ada kecenderungan jiwa manusia yang suci berhubungan dengan akal ini. Siapapun yang dapat berhubungan dan berkomunikasi dengan akal ini, maka ia akan mengenal atau mengetahui hakikat dari sesuatu.
\end{abstract}

Kata Kunci: Sumber Belajar dan Teori Pancaran.

\section{A. Pendahuluan}

Dalam teori-teori pendidikan dikatakan bahwa sumber belajar adalah segala sesuatu yang bisa dimanfaatkan guna kepentingan proses belajar, baik secara langsung maupun tidak langsung; sebagian atau keseluruhan dalam mencapai tujuan pembelajaran. Pengalaman seseroang adalah sumber belajar dalam arti luas, dan segala sesuatu yang dialami 
seseorang dianggap sebagai sumber belajar baik; pengalaman fisik, psikis maupun pengalaman spiritual.

Kehidupan manusia merupakan akumulasi dari berbagai pengalaman baik yang dirancang, dipersiapkan maupun yang diterima sebagaimana adanya. Kelahiran manusia ke dunia bukanlah suatu rancangan oleh dirinya sendiri tetapi dipersiapkan oleh pihak lain, dan manusia yang lahir menerima keberadaannya sebagaimana adanya, tanpa harus memilih dimana, kapan dan dari siapa ia akan dilahirkan. Namun demikian dalam kehidupan selanjutnya ia merancang dan mempersiapkan kehidupannya dengan pengalaman hidup sebagaimana ia inginkan. Walaupun demikian tidak semua keinginan hidupnya dapat diwujudkan karena ketidakmampuannya untuk mempersiapkan dan mengendalikan segala sesuatu yang berada di luar batas kemampuannya.

Dimensi fisik dan psikis manusia memang tunduk kepada hukum-hukum sebagaimana disebutkan di atas, tetapi pada aspek spiritual manusia tidak sepenuhnya mengikuti sebagaimana disebutkan tadi. Ketika manusia ingin mendekati Tuhan dalam suasana keintiman, ada usaha-usaha yang bisa dilakukan dengan berbagai macam mujahadah, riyadlah sebagai usaha tazkiyah al-nafs. Namun tidak semua usaha yang dilakukannya selalu membawa hasil, karena kedekatan dengan Tuhan yang tanpa diperantarai oleh jarak itu bukan semata usaha manusia semata, tetapi sangat bergantung kepada rahmat Tuhan yang akan dilimpahkannya. Bilamana Tuhan menghendaki seseorang untuk mendekat kepada-Nya secara intim, maka Dia menariknya ke sisi-Nya (jadzb) sehingga ia mengenal-Nya dari dekat. 


\section{B. Pengalaman Ruhaniyah sebagai Rentetan Emanasi}

Kemungkinan pendidikan melalui pencapaian pengalaman ruhaniyah bisa ditelusuri dari kosmologi penciptaannya sebagai rentetan emanasi dari sebab pertama. Proses emanatif aspek spiritual adalah limpahan atau pancaran cahaya Ilahi. Tuhan sebagai realitas sederhana, keseluruhan hakikatnya -dengan kebesaran-Nya yang memanifestasikan diri sebagai sumber wujud- sama sekali melampaui kemampuan pengenalan kognitif, serta manusia hanya membentuk gagasan-gagasan yang amat kabur dan tidak sempurna.

Gagasan-gagasan itu dengan berani ditampilkan melalui konsep bahwa Tuhan itu adalah Wajib al-Wujud (الواجب الوجود), yaitu sesuatu yang harus ada, dan ketiadaannya menimbulkan kemustahilan. Dia tidak memerlukan identitas dan realitas yang bisa didefinisikan. Kepastian ada-Nya bisa disebabkan oleh dzat-Nya sendiri dan tidak oleh yang lain. Pemunculan dan manifestasi diri-Nya pada wujud yang lain memungkinkan kebenarannya bisa dibayangkan oleh nalar. Hanya pada Wajib al-Wujud yang esensi dan eksistensinya satu dan sama adalah kebenaran murni, sebagai ketuhanan murni dan asal segala wujud, ${ }^{1}$ sedangkan pada lain-Nya kesatuan esensi dan eksistensi hanya aksiden yang ditambahkan pada esensi. Perbedaan antara esensi dan eksistensi hanya merupakan pengenalan oleh nalar dan dalam realitasnya adalah satu dan sama. $^{2}$

Tuhan adalah azali (الازلي/tanpa permulaan) yang tidak memerlukan pada pencipta. Sifat dan dzat-Nya sesuai dengan

1 Hosen Nashr, An Introduction to Islamic Ontological Doctrines (New York: State University, 1993), 18.

2 Mir Valiudin,Tasawuf dalam Qur an, penterj: Pustaka Firdaus ( Jakarta: Pustaka Firdaus, 1993), 58. 
kekekalan-Nya tanpa memerlukan individualitas-Nya mewujudkan diri-Nya melalui cahaya-Nya dalam bentuk objek fenomena, dan sebagai entitas cerminan yang mengungkapkan hakikat-Nya yang ada dalam pengetahuan-Nya. Hal ini merupakan aspek ilahiyah yang dikaitkan dengan ciptaan fenomena. Pengetahuan tentang hakikatnya oleh diri-Nya menyebabkan sesuatu menjadi ada, sehingga pada dasarnya semua wujud yang lain berasal dari kehendak-Nya.

Wujud lain pada dasarnya bersumber pada yang satu yang dapat dilihat dari kesatuannya dan bukan dari keragamannya. Dia adalah sumber segala sesuatu; mengetahui segala sifat dan hakikat-Nya. Karena Dia disebut akal murni, maka pada saat yang sama merupakan tindak penalaran, serta sekaligus menjadi subjek dan objek nalar. Dia hanya berpikir tentang diri-Nya, dan tidak mungkin berpikir tentang realitas yang bersifat sementara dan wujud yang lebih rendah. ${ }^{3}$ Pengetahuan-Nya tentang diri-Nya sebagai sebab pengetahuanNya tentang alam semesta adalah mutlak, satu, dan sama. Maka eksistensi alam semesta adalah efek pengetahuan Tuhan tentang eksistensi tersebut, sedangkan pengetahuan tentang diri-Nya adalah wujud dzat yang diciptakannya.

Wujud selain Tuhan merupakan manifestasi dari Tuhan secara emanatif. Kepastian dari sistem emanasi sebagai suatu keharusan dan sebagai kemungkinan sebab penyerapan adalah kebergantungan secara total wujud mungkin kepada Tuhan. Suatu bentuk wujud muncul dan ditopang oleh wujud yang lain, baik dalam memasuki eksistensi maupun dalam melanjutkan eksistensi pada pihak lain di bawahnya. Hirarki emanasi itu menyiratkan kontinuitas dan kontingensi total mode emanatif yang lebih rendah pada prinsip-prinsip terdekatnya, baik yang berada dalam tingkat pertama maupun terakhir.

${ }^{3}$ Ibid., 249. 
Wujud emanatif tidak pernah dilepaskan dari sumbernya dengan berdiri sendiri sebagai entitas yang mandiri. Wujud emanatif tetap eksis dalam ketergantungannya pada sumbernya. Ketergantungan murni terhadap yang lain, karena ia tidak mempunyai realitas dalam dirinya selain sebagai subordinat dari suatu realitas. Proses emanasi tidak menyerah pada kehampaan total, tetapi ada keterkaitan tak terputus antara berbagai level wujud emanatif dengan prinsip terdekatnya. ${ }^{4}$ Wujud emanatif tidak pernah mengalami perubahan substansi menjadi hakikat sumbernya, karena wujud emanatif mempunyai prinsip yang bersifat mungkin bagi dirinya sendiri.

Penciptaan kadang-kadang berarti pemberian wujud oleh Tuhan dan pemancaran cahaya dari sumber yang suci, sehingga penciptaan adalah suatu realitas dan eksistensi yang dapat dipikir sebagai tajalli (تجلى/ manifestasi) dari-Nya. Emanasi ke arah luar diserap oleh gerakan kembali kepada Tuhan. Terdapat ketersambungan/ relasi dalam rentetan emanatif antara wujud pertama dengan wujud berikutnya, sampai kepada wujud manusia. Hubungan manusia dengan Tuhan diperantarai oleh akal-akal, dari akal pertama sampai akal kesepuluh. Akal kesepuluh ini sering kali dikenal dengan sebutan malaikat Jibril (pembawa wahyu/llham) dan melimpahkannya kepada manusia secara emanatif pula.

\section{Akal Pertama}

Dalam spekulasi filosofis bahwa wujud pertama adalah esensi, sedangkan eksistensi adalah turunan atau konsep

4 Mehdi Ha'iri Yazdi, Ilmu Hudhuri, penterj.: Ahsin Muhammad (Bandung: Mizan, 1994), 223. 
mental. ${ }^{5}$ Wujud itu sebenarnya sebagai keseluruhan rangkaian kesatuan yang terdiri dari kesadaran diri dan monad ${ }^{6}$ mandiri yang tidak terpisahkan dari keseluruhan, dan dikenal oleh dirinya sendiri. Dengan jalan emanasi terjadilah penciptaan; dan wujud emanatif level teratas; dan al-'aql al-awwal العقل (الاول/ akal pertama) berada pada posisi ini. Wujud ini diidentifikasikan dengan berbagai macam nama atau sebutan, yang antara lain: al-'aql al-ula ( العقل الاولى/ akal pertama), al-'aql al-kulli (العقل الكلى / akal universal), al-malak ( الملى / malaikatmalaikat), ${ }^{7}$ cahaya abstrak, ${ }^{8}$ yang sebanding dengan intelek. ${ }^{9}$

Akal pertama atau kadang-kadang disebut dengan jiwa rasional-bersifat immaterial dan ia adalah ruh dunia. ${ }^{10}$ Dia adalah wajib al-wujud dalam dirinya sendiri atau menjadi sifat mungkin dalam esensinya, karena rahmat Tuhan. Akal ini sebagai substansi yang wujudnya tunggal, tetapi menerima bentuk dari wujud lain yang berasal dari Wajib al-Wujud yang esensi dan eksistensinya satu, yaitu kebenaran murni, dan sebagai sumber dan asal segala wujud. Jiwa rasional melalui aktivitas kesadaran diri mengkaitkan tatanan kosmik dengan

5 Ziai, Hossein, Filsafat Illuminasi, penterj.: Afif Muhammad dan Munir (Bandung: Zaman Wacana Mulia, 1988), 150.

${ }^{6}$ Monade dalam bahasa Yunani adalah monas atau satuan, yaitu satuan substansial yang bersifat tunggal tidak dapat dibagi, murni metafisik tanpa bentuk dan keluasan sebagai ciptaan Tuhan; dengan kerjanya bersifat immanen; dan mengungkapkan diri semata-mata di dalam dirinya sendiri dan oleh dirinya sendiri. Ali Mudhofir, Kamus Istilah Filsafat (Yogyakara : Liberty, 1992), 104.

${ }^{7}$ Abu Hamid Muhammad bin Muhammad al-Ghazali, Misykah al-Anwar (Kairo: Dar al-Fahm, 1964), 24-25.

8 John Tulltill, The Philosophy of Quthb al-Din al-Sirazi: a Study in Integration of Islamic Philosophy (Boston: Harvard University, 1983), 204.

${ }^{9}$ Hossein Ziai, Filsafat Illuminasi..., 80.

10 Hosen Nasr, An Introduction ....., 57. 
tatanan fisik melalui prinsip kesadaran langsung dalam berbagai tingkat intensitasnya. ${ }^{11}$

Oleh karena akal pertama adalah wujud mungkin, ia dapat menurunkan multiplisitas dalam dirinya sendiri ${ }^{12}$ sehingga ia menjadi sebab bagi yang lain. Ketika akal pertama ini berpikir wujud yang di atasnya (wujud pertama), maka timbullah wujud akal kedua. Dengan cara yang sama seperti di atas maka akal-akal itu mengadakan multiplisitas sampai akal kesepuluh atau al-'Aql al-Fa'al (العقل الفعال / Akal Aktif). ${ }^{13}$

Kepastian sistem emanasi yang melimpah sebagai suatu keharusan, dan kemungkinan sebab penyerapan adalah ketergantungan total wujud mungkin kepada Wajib al-Wujud, sebagai sebab-sebab pengetahuan. Akal pertama sebagai hirarki tertinggi dalam wujud kosmik hanya mempunyai suatu kemampuan dan kekuatan, yaitu pengetahuan yang diterima dari sebab pertama. Kekuatannya yang bersifat cahaya Ilahi ini dapat menyerap makna-makna yang tidak dimengerti oleh indera dan nalar. ${ }^{14}$ Pengetahuan yang diterimanya itu sebagai prototype dari ma'rifat (المعرفة / mengenal Allah). ${ }^{15}$ Oleh karena itu ia penuh dengan pengetahuan dan kekuatan, dan meguasai seni dan sains. ${ }^{16}$ Tentang Wajib al-Wujud, esensi dirinya sendiri sebagai Wajib al-Wujud karena karunia pihak lain, dan dirinya

\footnotetext{
${ }^{11}$ Hossein Filsafat Illuminasi..... , 139.

12 Ibid., 203.

13 M.M. Syarif, Para Filosof Muslim (Bandung: Mizan, 19930), 70-71; Harun Nasution, Filsaafat dan Mistisisme dalam Islam (Jakarta: Bulan Bintang, 1991), 27-30; A. Hanafi, Pengantar Filsafat Islam (Jakarta: Bulan Bintang, 1990), 9394.

${ }^{14} \mathrm{Abu}$ Hamid Muhammad bin Muhammad al-Ghazali, Misykah al-Anwar.....,1827.

15 Ibid., 204.

${ }^{16}$ Abu Hamid Muhammad bin Muhammad al-Ghazali, Kimiya al Sa'adah (Kairo: Dar al-Fahm, 1964), 14.
} 
sendiri sebagai wujud kontingensi, merupakan pengetahuan yang melekat pada dirinya. ${ }^{17}$

\section{Akal Aktif}

Diantara rentetan emanasi terdapat al-'Aql al-Fa'al ( العقل العقل (الفعال Active Intellect atau Akal Aktif), atau al-'aql al-'asyir العاشر/akal kesepuluh). Akal Aktif merupakan istilah lain untuk ruh suci atau malaikat Jibril, $^{18}$ dan sebagai substansi kemalaikatan $^{19}$ yang berupa cahaya. Di dalam wujud emanatif kesepuluh ini terdapat segala bentuk ${ }^{20}$ yang ada sejak azali (الازلى tanpa permulaan). ${ }^{21}$ Selain itu, ia sebagai sumber eksistensi jiwa, ${ }^{22}$ sumber hukum dan undang-undang bagi kehidupan moral dan sosial. ${ }^{23}$ Pengetahuan intuitif disampaikan melalui akal ini; dan yang tertinggi berupa wahyu dan ilham. $^{24}$ Dengan demikian wahyu dan ilham adalah

\footnotetext{
${ }^{17}$ Hosen Nasr, An Introduction...., 204.

18 Ibid., 268.

19 Muhammad Yasir Nasution, Manusia Menurut al Ghazali (Jakarta: Raja Grafindo Persada, 1996), 101.

20 Bentuk (al-shurah atau form) adalah struktur yang dapat dimengerti; ciri-ciri yang membentuk substansi yang dibedakan dengan materi di dalam mana ciriciri tersebut termuat, hakikat, sebab bentuk. Ali Mudhofir, Kamus......, 65. Dalam pandangan Sa'id Syaikh bahwa bentuk adalah esensi suatu benda yang menyatu dengan materi pertama (hayula membentuk benda tertentu dan sebenarnya merupakan prinsip yang menentukan materi pertama yang secara aktual menjadi benda semacam itu, tetapi tanpa materi atau bentuk tidak akan ada benda konkrit sama sekali. Sa'id Syaikh, Kamus Filsafat Islam, Penterj.: Machnun Husein (Jakarta: Rajawali, 1991), 85-86.

${ }^{21}$ Harun Nasution, Filsaafat...., 31.

22 Amin Abdullah, The Idea of Universality of Ethical Norm in Kant and Ghazali, (Ankara: Kutlu Dogu'a, 1993), 193.

23 Ibid., 90.

24 Hasan Langgulung, Asas-Asas Pendidikan Islam (Jakarta: Pustaka al-Husna, 1992), 282.
} 
pancaran emanatif dari Tuhan melalui Akal Aktif. ${ }^{25}$ Hubungan akal ini dengan seseorang sama dengan hubungan antara matahari dan mata. ${ }^{26}$

Ibnu Sina menisbatkan semua operasi intelektual kepada-Nya, dan membebaskan dari inisial apapun terhadap pikiran. Pikiran hanyalah melakukan persiapan diri -dengan melalui kondisi-kondisi kekuatan persepsi dan pemahamanuntuk menerima derajat yang sepadan bagi dirinya dengan intensitas cahaya yang lebih besar didapat dari spirit yang paling dekat dari sumbernya. ${ }^{27}$ Kekuatan akal ini tidak terkait dengan materi, karena ia sebagai causa (penyebab) terpisah dari materi, terutama ketika melakukan kegiatan intelektual, demikian menurut Ibn Rusyd. ${ }^{28}$

Wujud emanatif ini yang menerima pengetahuan langsung dari Tuhan dengan hanya menangkap arti-arti terlepas dari materi, sebagai akibat bentuk murni tanpa materi berada padanya. Akal Aktif mengandung berbagai prinsip gambar-gambar rasional yang bersifat abstrak, dan menjadi sumber pengetahuan akal. Pengetahuan seseorang secara spiritual dicapai dengan penyatuan eksistensial dengan Akal Aktif, $^{29}$ yang mempunyai potensi dan fungsi menghubungkan antara hamba dengan Tuhannya. ${ }^{30}$ Dalam tindak operasional akal yang penuh dengan keajaiban-keajaiban ini memancarkan pengetahuan yang berupa bentuk itu kepada seseorang dalam kenyataan tanpa bimbang dan ragu. ${ }^{31}$ Kemungkinan ini bisa

\footnotetext{
25 Ibrahim Madkur, Fi Falsafah al-Islamiyah ( Mesir: Dar al-Ma'arif, [tt]), 97.

${ }^{26}$ Harun Nasution, Filsafat ....., 31.

27 Mehdi Ha'iri Yazdi, Ilmu Hudhuri....., 36.

28 Ibid, 47.

${ }^{29}$ Mehdi Ha'iri Yazdi, Ilmu Hudhuri....., 43.

30 Muhammad 'Utsman Najati, Jiwa dalam Pandangan Filosof Muslim, Penterj. : Gazi Saloom (Bandung: Pustaka Hidayah, 2002), 228.

31 Hosen Nasr, An Introduction....., 20.
} 
dicapai, karena ada kecenderungan jiwa manusia suci berhubungan dengan akal ini. $^{32}$ Selanjutnya ia dapat mengadakan hubungan dengan Tuhan, sehingga mendapatkan wahyu atau ilham melalui Akal Aktif. ${ }^{33}$ Maka hubungan seseorang dengan Tuhan ditandai dengan pencerahan, yaitu pencerahan yang tidaklah keluar dari-Nya secara langsung, tetapi dengan perantaraan akal ini. ${ }^{34}$ Melalui akal ini -sebagai pengatur semua yang berada di muka bumi- ${ }^{35}$ siapapun yang dapat berhubungan dan berkomunikasi dengan akal ini, iapun mengenal atau mengetahui hakikat-hakikat tertentu. ${ }^{36}$

\section{E. Fisik Manusia}

Manusia terdiri dari unsur jasmani (biologis) dan ruhani (spiritual); dan setiap unsur mempunyai tuntutan dan kebutuhannya sendiri. Secara biologis ia terdiri dari unsur mineral, tumbuh-tumbuhan, dan hewan, serta secara spiritual ia mempunyai potensi kemalaikatan, karena sejak kejadiannya telah ditiupkan ruh ke dalamnya, sehingga tingkatannya lebih tinggi dari sekedar makhluk yang hanya mempunyai aspek biologis. Jasadnya yang dibangun dari tanah dapat berhubungan dengan dunia material dan aspek spiritualnya dapat berhubungan dengan Tuhan.

Asumsi dasar tentang manusia pada umumnya, bahwa ia tidak mempunyai kemampuan mengetahui segala yang dibutuhkan bagi kelangsungan dan kesempurnaan hidupnya sesuai dengan tuntutan hakikatnya. Tetapi dalam dirinya

\footnotetext{
32 Ibrahim Madkur, Fi Falsafah al-Islamiyah ....., 60.

33 Ibid., 90.

${ }^{34}$ Ibid., 51.

35 Ahmad Fuad al-Ahwani, Filsafat Islam, Suntingan: Sutardji Calzoum (Jakarta: Pustaka Firdaus, 1995), 146.

36 Harun Nasution, Filsafat ......, 31. 
terdapat sekumpulan potensi yang sangat diperlukan dan turut membangun kepribadiannya. Potensi yang kompleks itu terdiri dari berbagai macam daya yang dapat menempatkannya pada posisi antara sifat ketuhanan dan sifat kehewanan. ${ }^{37}$ Unsur kehewanannya terdapat dalam aspek fisik, dan unsur ketuhanan terdapat dalam dirinya yang ada sejak diciptakan dalam alam ruh, ${ }^{38}$ maka ia mempunyai kemampuan untuk berada dalam berbagai dataran yang berbeda, mulai yang terendah sampai tertinggi. ${ }^{39}$

Manusia adalah potensi citra yang meliputi segala jenis apa saja yang ada dalam alam ini; seakan-akan ia adalah segalagalanya yang berada dalam alam; ${ }^{40}$ atau sebagai mikrokosmos yang mempunyai semua derajat eksistensi dalam dirinya, dan mempuyai akal sebagai prinsip batiniyah dari wujudnya. ${ }^{41}$

Indera sebagai bagian dari aspek biologisnya, bagaikan jendela yang terbuka menghadap ke dunia luar, sehingga dapat melakukan pemgamatan dan menerima kesan-kesan. Ia juga mempunyai daya nalar yang memungkinkan ia berpikir. Oleh karena itu ia berada di antara dunia penginderaan dan penalaran. Tetapi yang lebih ajaib dari itu, ruhnya memiliki jendela yang terbuka ke alam spiritual yang tidak kasat mata, ${ }^{42}$ dan tidak bisa dipersepsikan dengan penalaran. Ketika aspek fisik dan nalar terbatas kemampuannya, maka instrumen ruhani berperan untuk mencapai sesuatu yang supra rasional dan supra natural. Dengan bantuan Akal Aktif ia dapat

\footnotetext{
37 Ahmad Fuad al-Ahwani, Filsafat Islam ....., 101.

38 Hasan Langgulung, Asas-Asas Pendidikan....., 294.

${ }^{39}$ Abu Hamid Muhammad bin Muhammad al-Ghazali, Kimiya al Sa'adah ......, 61.

${ }^{40}$ Abu Hamid Muhammad bin Muhammad al-Ghazali, Misykah al-Anwar ......, 70.

${ }^{41}$ Hosen Nasr, An Introduction ....., 41 dan 259.

42 Abu Hamid Muhammad bin Muhammad al-Ghazali, Kimiya' al- Sa'adah ....... 14.
} 
mengarahkan pandangannya ke realitas malaikat dan akal murni. $^{43}$

Keberadaaan fisik dan anggotanya dalam hubungannya dengan aspek spiritual hanya sebagai kendaraannya. Badan tetap diperlukan bagi aspek spiritual walaupun hanya bersifat instrumental. ${ }^{44}$ Aspek ruhani sebagai esensi manusia ${ }^{45}$ adalah aspek terdalam kepribadiannya, dan mempunyai peran yang sangat penting. Penglihatan ruhani tidak terbatas pada limitasi material, karena dilihat oleh sesuatu yang eksistensinya tidak tergantung pada tubuh. ${ }^{46}$

\section{F. Jiwa Manusia}

Jiwa terpisah dari tubuh, karena ia bersifat tetap sedangkan tubuh berubah, maka ia lebih utama daripada tubuh; ${ }^{47}$ baik ketika berhubungan dengan tubuh atau tidak. Ia merupakan substansi yang dapat mengenali hal-hal yang rasional dan makna yang universal. ${ }^{48}$ Esensi jiwa suci dapat menangkap sesuatu yang dapat dinalar secara potensial mandiri, karena ia mempunyai kesadaran diri. Jiwa meliputi beberapa substansi, dari akal yang paling atas sampai potensi dan kemampuan seseorang yang paling rendah seperti sifat nabatiyah-nya. ${ }^{49}$

Jiwa mempunyai dorongan nafsu nabatiyah sampai al'Aql al-Mustafad. Dengan nafsu nabatiyah-nya seseorang dapat berhubungan dengan alam duniawi. Dengan nafsu binatangnya

\footnotetext{
${ }^{43}$ Hosen Nasr, An Introduction ....., 258.

44 Muhammad Nasution, , Manusia ......, 190.

45 Hossein Ziai, Filsafat Illuminasi...., 139.

46 A.E. 'Afifi, Filsafat Mistis Ibnu 'Arabi, penterj.: Sjahrir Mawi dan Nandi Rahman (Jakarta: Gaya Media Pratama, 1995), 161.

47 Ibrahim Madkur, Fi Falsafah al-Islamiyah ....., 235.

48 Ibid., 229.

${ }^{49}$ Hosen Nasr, An Introduction ....., 202. 
ia dapat melakukan gerakan dan tindak mengetahui, dan dengan akalnya ia mempunyai potensi untuk berpikir sesuatu dari yang konkrit sampai yang abstrak. Ketika jiwa mengenali dan meliput sesuatu, ia merupakan substansi ruhani. ${ }^{50}$ Oleh karena itu jiwa mempunyai penginderaan alam rabbany yang penuh dengan bentuk segala sesuatu dan dunia materi. ${ }^{51}$

Human soul (النفس الناطقة/ jiwa manusia) yang diberikan kepada setiap wujud manusia oleh Akal Aktif sebagai tambahan untuk kesempurnaan jiwa vegetatif (tumbuh-tumbuhan) dan animal (hewani), sehingga ia mempunyai tindakan yang berada di antara dunia bentuk dan dunia materi. Untuk memikirkan sesuatu manusia mempunyai akal yang dapat mencapai alam kemalaikatan melalui bantuan Akal Aktif. ${ }^{52}$ Akibat peran Akal Aktif menyebabkan pikiran mengadakan transformasi dari Akal Material (potensial) -sebagai tingkatan akal yang paling rendah- menuju ke Akal Habitual -suatu tingkatan akal yang berada di atasnya- atau mencapai tingkatan yang lebih tinggi lagi, yaitu Akal Aktual dan Akal Mustafad. ${ }^{53}$

Ketika Akal Aktif berhubungan dengan jiwa seseorang, jiwa itu mendapat pancaran cahayanya maka ia menjadi $a l-' A q l$ al-Mustafad karena Akal Aktif sebagai wahib al-shuwar (الواهب الصور/ pemberi bentuk), sehingga fungsi jiwa itu dapat menangkap arti-arti dan bentuk-bentuk. Jika ia telah melepaskan diri dari kendala fisik, ia akan mengalami cahaya penyingkapan (الانوار السا نخة), kemudia ia disebut dengan jiwa abstrak, karena ia telah memperoleh cahaya Tuhan. Jiwa yang bersih jernih mendapat faydl ( الفيض/ limpahan) cahaya secara

50 Ibrahim Madkur, Fi Falsafah al-Islamiyah....., 231.

${ }^{51}$ Hosen Nasr, An Introduction ....., 269.

52 Ibid.. 258.

53 Ibrahim Madkur, Fi Falsafah al-Islamiyah ......, 51-52. 
terus-menerus dan bersambung-sambung dari cahaya Tuhan. Maka kesempurnaannya terletak pada geraknya menuju padaNya, ${ }^{54}$ mencintai-Nya dan dekat pada-Nya. ${ }^{55}$

Akal dalam merambah jalan peningkatan dan perkembangannya melalui fase-fase yang satu sama lain saling menopang karena pada awalnya ia merupakan akal potensial, tetapi jika ia telah mempersepsi sebagian besar pengetahuan yang umum dan realitas-realitas yang universal, maka ia akan menjadi Akal Aktual. Batas pandangannya melampaui pandangan universal, maka ia meningkat menuju tahapan tertinggi yang bisa dicapai, yaitu derajat Akal Mustafad (Acquired Intelect/ Akal Limpahan) atau derajat emanasi dan inspirasi. ${ }^{56}$ Oleh karena itu kesempurnaan akal apabila mencapai derajat mustafad, dan pada derajat itulah kesempurnaan manusia terwujud. ${ }^{57}$ Apabila akal menjadi Akal Mustafad, ia berhak menerima cahaya Ilahi dengan segera berhubungan langsung dengan Akal Aktif.

\section{G. Perolehan Pengalaman dan Pegetahuan dari Sumbernya Secara Emanatif (Pancaran)}

Persepsi inderawi dan nalar sebagai langkah pertama dalam membuka dan menyiapkan akal untuk pengetahuan rasional. Pada dasarnya pengetahuan rasional tidak diperoleh melalui jalur inderawi, tetapi melalui jalur luar akal, atau ilham dan emanasi dari Akal Aktif, yaitu akal yang terpisah dari materi. ${ }^{58}$ Interaksi keduanya memungkinkan terjadinya intuisi

\footnotetext{
54 Ibrahim Madkur, Fi Falsafah al-Islamiyah ...., 80.

55 Muhammad Yasir Nasution, Manusia...... 124.

56 H.M. Amin Syukur dan Masyharudin, Intelektualisame Tasawuf (Semarang: Lembkota, 2002), 93.

${ }^{57}$ Muhammad 'Utsman Najati, Jiwa ....., 168.

58 Ibid., 171-228 
yang tumbuh pada diri manusia tanpa didahului keterangan logis dan tidak bergantung pada pengamatan inderawi, ${ }^{59}$ sehingga tidak terbatas pada persepsi inderawi yang nisbi, tetapi dapat meningkat pada serapan-serapan pengetahuan yang bersifat mutlak.

Jika akal menelaah gambar-gambar inderawi yang ada dalam konsepsi, dan Akal Aktif melakukan hubungan dengannya, maka ia siap untuk menangkap makna-makna umum dalam perspektif Akal Aktif. Sebagaimana juga hubungan pengetahuan empirik dan rasional dengan pengetahuan intuitif sebagai produk akal dalam level yang berbeda dapat dilihat bahwa akal sebagai sarana yang berfungsi untuk memperoleh pengetahuan yang benar. $^{60}$ Disamping itu akal sebagai suatu model emanasi diciptakan untuk mencapai tingkat realisasi diri secara mutlak. Namun karena realisasi akal terikat pada prinsip-prinsip hirarkhi emanasi, dan secara mutlak terserap ke dalam Wajib al-Wujud, maka proses realisasi diri itu lebih menyerupai semacam identifikasi proposisi (keruntutan) hubungan dengan Dzat Yang Maha Esa. ${ }^{61}$

Akal pada hakikatnya substansi ruhaniyah yang menjadikan seseorang dapat memahami hakikat kebenaran ruhaniyah. Menurut Plato, akal mempunyai kemampuan penampakan terhadap objek transenden, sehingga bentukbentuk objek yang terfahami dari pengetahuan transenden memiliki eksistensi yang nyata dan merupakan wujud dalam dirinya sendiri dan tidak bergantung pada proses pemikiran maupun objek fisik tersendiri yang berada dalam dunia

59 H.M. Amin Syukur, Tasawuf Sosial (Yogyakarta : Pustaka Pelajar, 2004), 2627; dan H.M. Amin Syukur dan Masyharudin, Intelektualisame...., 87.

60 Al-Ghazali, Abu Hamid Muhammad bin Muhammad, Ihya' 'Ulum al-Din, Juz III ....., 42 dan 82.

61 H.M. Amin Syukur dan Masyharudin, Intelektualisame....., 99. 
menjadi. ${ }^{62}$ Dengan demikian dunia transenden dapat difahami oleh akal. Sedangkan bagi Aristoteles pengetahuan akal adalah abstraksi bentuk-bentuk objek spasio temporal. ${ }^{63}$ Pengetahuan akal menurut Ibn Sina maupun al-Farabi diperoleh berdasarkan emanasi diri dan unifikasi dengan intensitas yang terpisah, yaitu ide atau bentuk-bentuk Ilahi. ${ }^{64}$

Akal merupakan aktivitas seseorang paling mulia dan merupakan bagian dari akal Ilahi, dan memiliki peran yang penting dalam menjawab segala persoalan. ${ }^{65}$ Kekuatan akal seringkali disebut pula dengan cahaya Ilahi, karena mendapat bimbingan cahaya iman ${ }^{66}$ - dapat menyerap makna-makna yang tidak dapat dicapai oleh indera. ${ }^{67}$ Hal-hal rasional yang ada pada Akal Aktual segera tergambar dalam Akal Mustafad tanpa susah payah. Akal Mustafad mempunyai potensi dan fungsi penampakan terhadap objek transenden, menyingkap arti dan bentuk tanpa materi. Jika hal-hal rasional sampai kepadanya, maka ia adalah cahaya yang mendapat cahaya Akal Mustafad, ${ }^{68}$ sehingga mampu menerima emanasi dan ilham dari Akal Aktif yang terpisah dari jiwa. ${ }^{69}$ Kesempurnaan akal apabila mencapai derajat mustafad dan pada derajat itulah kesempurnaan manusia terwujud. Ia adalah derajat kesempurnaan yang tertinggi tetapi berbeda dengan Akal Aktif. Ketika seseorang berada pada derajat kesempurnaan intelektual -sebagai

\footnotetext{
62 Mehdi Ha'iri Yazdi, Ilmu Hudhuri....., 23.

63 Muhammad Yasir Nasution, Manusia....., 25-26.

${ }^{64}$ Mehdi Ha'iri Yazdi, Ilmu Hudhuri....., 39.

65 Karen Amstrong, Sejarah Tuhan, penterj.: Zainul Am (Bandung: Mizan, 2002), 249.

66 Muhammad 'Abdullah al-Syarqawi, Sufisme dan Akal, penterj.: Halid al-Kaf (Bandung: Pustaka Hidayah, 2003), 179 dan 228.

67 Abu Hamid Muhammad bin Muhammad al-Ghazali, Cinta dan Bahagia, penterjemah: Abdullah bin Nuh (Jakarta : Tinta Mas, 1992), 8.

68 Ibid, 223.

${ }^{69}$ Muhammad 'Abdullah al-Syarqawi, Sufisme....., 117.
} 
realisasi diri yang sempurna- maka semua potensialitasnya menjadi aktual yang menyebabkan tidak adanya potensi dan tindakan, karena hubungan aksi dan potensi ini telah berakhir. Ketiadaan aksi ini mengakibatkan tidak adanya aksi immanen dalam pikirannya atau ia berada dalam pengetahuan yang sempurna.

Kesempuraan akal memungkinkan ia menerima pengetahuan dan pengalaman secara langsung tanpa perantaraan indera maupun nalar, yaitu pengatahuan yang bebas dari simbolisme apapun dan hal ini kadang-kadang disebut dengan pengetahuan intuitif. Pengetahuan intuitif mengatasi sifat lahiriyah pengetahuan simbolis yang pada dasarnya bersifat analisis, tetapi ia memberikan pengetahuan tentang objek secara keseluruhan yang mutlak tanpa suatu ungkapan. Pengetahuan analisis atau pengetahuan yang diperoleh melalui jalan pelukisan tidak akan dapat menggantikan hasil pengenalan secara langsung dari pengetahuan intuitif. ${ }^{70}$ Pengetahuan intuitif sejenis pengetahuan yang dikaruniakan Tuhan kepada seseorang dan dipatrikan pada kalbunya sehingga tersingkap olehnya segala rahasia dan tampak olehnya sebagian realitas.

Pengetahuan dan pengalaman yang dicapai dengan cara demikian sebagai pengetahuan pemberiaan. Kondisi ini menyebabkan ia memperoleh kemampuan untuk menerima pencerahan Akal Aktif dalam segala hal, karena Akal Aktif mengandung berbagai prinsip gambar-gambar rasional yang bersifat abstrak. Bentuk-bentuk akali yang tersimpan dalam Akal Aktif akan beremanasi pada jiwa, kemudian pengetahuan itu difahami dan diterima dengan mudah. ${ }^{71}$ Intuisi sebagai

70 Louis 0 Kattsoff, Pengantar Filsafat, penterj.: Soejono Soemargono (Yogyakarta: Tiara Wacana, 1992), 146.

${ }^{71}$ H.M. Amin Syukur dan Masyharudin, Intelektualisame ...., 101. 
naluri yang menjadi kesadaran diri dapat menuntun pada kehidupan immateri. Seseorang yang memperolehnya, memungkinkan untuk mendapatkan pengetahuan langsung yang mengatasi pengetahuan yang diperoleh lewat indera dan akal. $^{72}$ Karena ia sebagai sarana untuk mengetahui secara langsung dan seketika. ${ }^{73}$ Bahkan jika intuisi dapat meluas dan mendominasi kehidupan manusia ia dapat memberi petunjuk vital, yaitu dorongan ruhani dari dalam dan langsung. Intuisi yang baik adalah yang dialami oleh orang-orang yang sudah lama berkecimpung dalam bidang tertentu.

Agar pengetahuan intuitif dapat diterima, maka harus disandarkan kepada moralitas subjek, ${ }^{74}$ akal sehat, dan keahlian subjek. Sebagai pengetahuan yang wataknya berbeda dan lebih tinggi dari pengetahuan indera dan akal, maka ia sama dengan cahaya kenabian atau pengalaman ma'rifah, ${ }^{75}$ yaitu pengetahuan dengan pengenalan langsung, yang secara eksklusif masuk dalam jiwa atau hati. ${ }^{76}$ Pengenalan ma'rifah melalui al-qalb, tanpa belajar melainkan lewat kasyf dan ilham. Karena ia didapatkan dalam alam rabbaniyah (الربانية) ketuhanan). Pengetahuan rabbaniyah mengaitkan manusia dengan alam ghaib, dan hasilnya disebut dengan berbagai macam term diantaranya: 'ilm al-asrar (العلم) الاسرار, 'ilm ladunni (العلم لدن)(الالهام), ma'rifah (المعرفة), ilham dain sebagainya. Prosesnya tiada diketahui bagaimana dan dimana diperolehnya. Ilham adalah peringatan Allah kepada jiwa jika ia telah mencapai kadar kejernihan dan kekuatan isti'anah (الاستعانة)

72 Ibid, 70-72.

${ }^{73}$ Louis O. Kattsoff, Pengantar ....., 146.

74 Ibid., 124.

75 Al-Ghazali, Abu Hamid Muhammad bin Muhammad, Ihya' 'Ulum al-Din, Juz III ....., 3.

76 H.M. Amin Syukur dan Masyharudin, Intelektualisame....., 73. 
pertolongan) tertentu, sehingga ia mampu memperoleh pengetahuan tanpa perantara antara dirinya dengan Allah SWT.

Pengetahuan rabbaniyah atau ladunniyah adalah tingkatan tertinggi pengetahuan yang dicapai melalui berbagai mujahadah dan riyadlah. Dengan demikian komposisi manusia paling sempurna mempunyai tiga unsur, yaitu: ruh dengan kecakapan aqliyah-nya, jiwa dengan sifat hawa nafsunya, dan badan dengan sifat penginderaaanya. Ketiga dapat bekerja saling inklusif secara sinergis untuk membangun satu kesatuan menuju terwujudnya manusia yang semua potensilitasnya berekembang memenuhi kodrat hidupnya.

\section{H. Emanasi Pengetahuan dan Pengalaman dari Akal Aktual ke Akal Mustafad}

Akal Mustafad merupakan suatu subtansi untuk melihat alam supra natural dan supra rasional, walaupun dengannya ia tidak sampai mencapai level kenabian, yaitu tingkat lebih tinggi yang menyebabkan seseorang dapat melihat alam ghaib berserta rahasia-rahasianya. ${ }^{77}$ Daya seseorang untuk mencapai pengetahuan tertinggi (pengetahuan tentang Tuhan) dan pengetahuan tentang hakikat yang lainnya melalui akal ini, karena ia dapat berhubungan langsung dengan Akal Aktif. Akal ini bagian dari jiwa atau beberapa potensi jiwa atau segala sesuatu yang dzatnya dipersiapkan (untuk menangkap pengetahuan). ${ }^{78}$ Kemampuannya dapat menangkap pure form (bentuk murni), yaitu arti-arti terlepas dari materi (abstracted intelegible).

\footnotetext{
${ }_{77}$ Abu Hamid Muhammad bin Muhammad al-Ghazali, al- Munqidz min a-Dlalal (Beirut: al-Sab'iyah, tt), 49.

78 Muhammad 'Abdullah al-Syarqawi, Sufisme ......, 116.
} 
Apabila sesuatu yang mawjud dan forma-nya terlepas tanpa materinya berarti keseluruhannya menjadi forma bagi segala yang mawjud itu, sehingga ia menyadari pengetahuan itu secara aktual, dan menyadari kesadarannya secara faktual. Akal ini bersifat pasif dan hanya mampu menerima pengetahuan dari Akal Aktif. Pengetahuannya yang bersifat perolehan dari akal yang selamanya aktual itu dan dengan sebab itu ia menjadi aktual. Pengetahuan perolehan ini bersifat hakiki dan hanya dapat diperoleh dengan syarat melepaskan diri dari ketergantungan terhadap duniawi, dan berfikir secara kontemplatif tentang wujud, ${ }^{79}$ sehingga wujud ruhaniyahnya menarik ke atas untuk merubah seseorang ke arah tingkat malaikat, dan beroperasi dalam alam supra duniawi, yaitu di luar batas ruang dan waktu. ${ }^{80}$ Ia dapat memandang sesuatu sebagaimana adanya, dengan syarat harus kosong dari wahm (هو/imajinasi). Bila kesadaran seseorang tidak lagi diperantarai pikiran apapun, maka dapat dibangun komunikasi intelektual dengan objek terfahami yang pada puncaknya adalah pemahaman terhadap Akal Aktif. ${ }^{81}$ Dengan demikian bahwa di balik akal ada kondisi lain yang dapat menyerap keajaiban yang tak terjangkau oleh akal dan indera. ${ }^{82}$

Sebagai ciptaan yang berasal dari pemikiran Tuhan, seseorang menjadi terintegrasi dalam archetype suci ${ }^{83}$ dalam tindakan inteleksi. ${ }^{84}$ Jika alam secara global timbul dari pancaran emanasi, maka aspek ruhani bisa mencapai keindahan-Nya dengan perantaraan emanasi dan pancaran. ${ }^{85}$

\footnotetext{
${ }^{79}$ Harun Nasution, Filsafat ......, 117-181.

${ }^{80}$ Hasan Langgulung, Asas-Asas Pendidikan......, 28-29 dan 76.

81 Mehdi Ha'iri Yazdi, Ilmu Hudhuri....., 43.

82 Abu Hamid Muhammad bin Muhammad al-Ghazali, Misykah al-Anwar ......, 83.

${ }^{83}$ Kecenderungan pokok untuk mewujudkan diri, Ali Mudhofir, Kamus ....., 15.

${ }^{84}$ Hosen Nasr, An Introduction ....., 259.

85 Ibrahim Madkur, Fi Falsafah al-Islamiyah....., 60.
} 
Jika seseorang dapat berhubungan dengannya, ia dapat mempersepsi berbagai macam pengetahuan, karena ruhnya dapat berhubungan dengan jiwa samawi yang akan menolongnya menyingkap kebaikan. ${ }^{86}$ Akal Aktif memberikan kecerdasan yang diperoleh melalui iluminasi kepada akal sehingga menyebabkan daya jiwa berfungsi secara penuh dan dapat menerima ide-ide yang datang dari al-ma'qul (لمعقول) sesuatu yang rasional) dan spiritual.

Dalam wacana sufistis, pengetahuan itu diperoleh karena sifat dan substansi ruh merupakan pancaran cahaya Tuhan, maka ia dapat menangkap ilmu-ilmu yang ada pada Tuhan. Al-ruh dapat menangkap, mencerap pengetahuan dari level yang tertinggi -pengetahuan yang diperoleh tanpa daya upaya terhadap objek non fisik- sampai terendah yang dicapai melalui usaha belajar terhadap objek fisik dan rasional. Seperti al-Ghazali dan al-Farabi mempercayai adanya pengetahuan batin di balik realitas fisik.

Pengalaman manusia secara empirik didapat dari pengalaman inderawi sedangkan pengetahuaan rasional dikonsep oleh nalar melalui premis-premis yang dapat dipikirkan secara logis. Melalui nalar seseorang bergerak dari yang telah diketahui ke arah yang tidak diketahui dan mendapatkan pengetahuan melalui penyelidikan dan penemuan. ${ }^{87}$ Pengalaman lainnya yang bersifat ruhani dicapai melalui emanasi dari akal Aktif ke Akal Mustafad ketika terdapat hubungan secara intim antara keduanya. Emanasi (الفيض) adalah sesuatu yang dengannya sebuah eksistensi dilahirkan dari yang lain, dan bergantung pada eksistensi lain tanpa perantaraan materi, instrumen, ataupun waktu.

86 Ibid., 60-61.

87 Ali Ashraf, Horison Baru Pendidikan Islam, penterj.: Sori Siregar (Jakarta: Pustaka Firdaus, 1989), 27. 
Abd. Kadir

\section{Kesimpulan}

Kepastian sistem emanasi sebagai suatu keharusan sumber emanasi dan sebagai kemungkinan bagi wujud emanatifnya, karena adanya penyerapan dan kebergantungan secara total wujud yang mungkin kepada sumber emanasinya. Hirarki emanasi itu menyiratkan kontinuitas dan kontingensi total model emanatif yang lebih rendah pada prinsip-prinsip terdekatnya, baik yang berada dalam tingkat pertama maupun terakhir. Wujud emanatif tidak pernah dilepaskan dari sumbernya dengan berdiri sendiri sebagai entitas yang mandiri. Wujud emanatif tetap eksis dalam ketergantungannya pada sumbernya. Ketergantungan murni terhadap yang lain, karena ia tidak mempunyai realitas dalam dirinya selain sebagai subordinat dari suatu realitas. Proses emanasi tidak menyerah pada kehampaan total, tetapi ada keterkaitan tak terputus antara berbagai level wujud emanatif dengan prinsip terdekatnya. Dengan demikian sumber terdekatnya memberikan pencerahan kepada suatu wujud emantif.

\section{DAFTAR PUSTAKA}

Abu Hamid Muhammad bin Muhammad al-Ghazali, Kimiya al Sa'adah (Kairo: Dar al-Fahm, 1964). , Misykah al-Anwar (Kairo: Dar al-Fahm, 1964). , Ihya' 'Ulum al-Din, Juz III. , Al- Munqidz min al-Dhlalal (Beirut: al-Sab'iyah, tt). Cinta dan Bahagia, penterjemah: Abdullah bin Nuh (Jakarta : Tinta Mas, 1992).

A.E. 'Afifi, Filsafat Mistis Ibnu 'Arabi, penterj.: Sjahrir Mawi dan Nandi Rahman (Jakarta: Gaya Media Pratama, 1995). 
Ahmad Fuad al-Ahwani, Filsafat Islam, Suntingan: Sutardji Calzoum (Jakarta: Pustaka Firdaus, 1995).

Ali Ashraf, Horison Baru Pendidikan Islam, penterj.: Sori Siregar (Jakarta: Pustaka Firdaus, 1989).

Amin Abdullah, The Idea of Universality of Ethical Norm in Kant and Ghazali, (Ankara: Kutlu Dogu'a, 1993).

Ali Mudhofir, Kamus Istilah Filsafat (Yogyakara : Liberty, 1992).

A. Hanafi, Pengantar Filsafat Islam (Jakarta: Bulan Bintang, 1990). Hosen Nashr, An Introduction to Islamic Ontological Doctrines (New York: State University, 1993).

Hossein Ziai, Filsafat Illuminasi, penterj.: Afif Muhammad dan Munir (Bandung: Zaman Wacana Mulia, 1988).

Harun Nasution, Filsaafat dan Mistisisme dalam Islam (Jakarta: Bulan Bintang, 1991).

Hasan Langgulung, Asas-Asas Pendidikan Islam (Jakarta: Pustaka al-Husna, 1992).

H.M. Amin Syukur dan Masyharudin, Intelektualisame Tasawuf (Semarang : Lembkota, 2002).

H.M. Amin Syukur, Tasawuf Sosial (Yogyakarta : Pustaka Pelajar, 2004).

Ibrahim Madkur, Fi Falsafah al-Islamiyah ( Mesir: Dar al-Ma'arif, $\mathrm{tt})$.

John Tulltill, The Philosophy of Quthb al-Din al-Sirazi: a Study in Integration of Islamic Philosophy (Boston: Harvard University, 1983).

Karen Amstrong, Sejarah Tuhan, penterj.: Zainul Am (Bandung: Mizan, 2002).

Louis 0 Kattsoff, Pengantar Filsafat, penterj.: Soejono Soemargono (Yogyakarta: Tiara Wacana, 1992).

Muhammad 'Utsman Najati, Jiwa dalam Pandangan Filosof Muslim, Penterj. : Gazi Saloom (Bandung: Pustaka Hidayah, 2002). 
Abd. Kadir

Muhammad 'Abdullah al-Syarqawi, Sufisme dan Akal, penterj.: Halid al-Kaf (Bandung: Pustaka Hidayah, 2003).

Mir Valiudin,Tasawuf dalam Qur an, penterj: Pustaka Firdaus ( Jakarta: Pustaka Firdaus, 1993).

Mehdi Ha'iri Yazdi, Ilmu Hudhuri, penterj.: Ahsin Muhammad (Bandung: Mizan, 1994).

M.M. Syarif, Para Filosof Muslim (Bandung: Mizan, 19930).

Muhammad Yasir Nasution, Manusia Menurut al Ghazali (Jakarta : Raja Grafindo Persada, 1996).

Sa'id Syaikh, Kamus Filsafat Islam, Penterj. : Machnun Husein, (Jakarta: Rajawali, 1991). 